\title{
Focal Treatment Alternatives in Prostate Cancer
}

\author{
Prostat Kanserinde Fokal Tedavi Alternatifleri
}

\author{
Mert Ali Karadağ', Kürșat Çeçen'1, Aslan Demir', Murat Bağcıoğlu', Ramazan Kocaaslan', Mustafa Sofikerim² \\ ${ }^{1}$ Department of Urology, Kafkas University Medical Faculty, Kars, Turkey; ${ }^{2}$ Department of Urology, Acıbadem University Medical \\ Faculty, Istanbul, Turkey
}

\begin{abstract}
The destiny of prostate cancer patients has been dramatically changed since the introduction of prostate specific antigen (PSA) into clinical use in late 1980s. Currently more men are diagnosed with localized, small, less aggressive and non-lethal prostatic carcinoma. Besides radical prostatectomy, cryosurgical ablation of the prostate, brachytherapy and high-intensity focused ultrasound have been accepted as alternative treatment options in clinically localized prostatic carcinoma.

In this review, we aimed to evaluate the success and complication rates of alternative focal treatment options as the primary outcome. The secondary outcome of this review was to define the candidate patients eligible for these procedures.

We searched the Medline using specified expressions including "focal treatment alternatives of prostatic carcinoma", "high-intensity focused ultrasound and cryosurgery of prostatic carcinoma" and "radiofrequency ablation of prostatic carcinoma". A total of 1173 papers related to the focal treatment options were analyzed and only 45 of them related to the subject were included.

There wasn't a controlled trial dealing with the topic. American Urologic Association guidelines have accepted cryosurgical ablation of the prostate as a therapeutic option; however the high-intensity focused ultrasound is still considered as an experimental treatment option, although it has been developed as a minimally invasive procedure with reduced morbidity and potentially with the same therapeutic efficacy in comparison with the surgical or non surgical options.

For patients meeting the variable criteria for regular follow up visits without intervention but experiencing anxiety with the feeling of losing active treatment options, focal therapies may be ideal alternatives. However, focal therapy options should be spared for patients with low to moderate risks. The radiologic and clinical stages should be below $T 2 b$ and $T 2 a$, respectively. In addition, all candidates should be informed that the alternatives are considered as experimental and they may need an alternative treatment option in time. Focal therapy alternatives may be more realistic treatment options in the near future; however, well designed multicenter prospective randomized trials are required to provide evidence based data.
\end{abstract}

Key words: cryotherapy; high-intensity focused ultrasound ablation; minimally invasive surgical procedures; prostatic neoplasms; therapeutics

Yard. Doç. Dr. Mert Ali Karadă̆, Kafkas Üniversitesi T⿰力 Fakültesi, Üroloji Anabilim Dal, Kars, Türkiye, Tel. 5325584324 Email. karadagmert@yahoo.com Geliş Taribi: 13.03.2014 • Kabul Taribi: 03.02.2015

\section{ÖZET}

1980'lerin sonundan itibaren, prostata özgü antijenin (prostate specific antigen, PSA) klinikte kullanılmaya bașlanmasıla prostat kanseri hastalarının kaderi dramatik olarak değiști. Günümüzde daha fazla sayıda erkek lokalize, küçük, daha az agresif ve ölümcül olmayan prostat kanseri tanısı almaktadır. Klinik olarak lokalize prostat kanserinin tedavisinde, günümüzde radikal prostatektominin yanı sıra, prostatın kriyo-cerrahi ile ablasyonu, brakiterapi ve yüksek yoğunluk odaklı ultrasonografi de alternatif tedavi seçenekleri olarak kabul edilmektedir.

$\mathrm{Bu}$ derlemede, birincil sonuç olarak lokalize prostat kanserinde fokal tedavi alternatiflerinin bașarısı ve komplikasyon oranları belirlemeyi amaçladık. Derlemenin ikincil sonucu ise bu ișlemler için uygun olan aday hastaların tanımlanmasıydı.

"Prostat kanserinin fokal tedavi alternatifleri", "yüksek yoğunluk odaklı ultrasonografi ve prostat kanserinin kriyocerrahisi" ve "prostat kanserinin radyofrekans ablasyonu" tanımlamalarıla Medline taraması yaptık. Toplamda 1173 makale değerlendirildi ve bunlardan içerik olarak uygun bulunan 45 tanesi derlemede kullanıldı.

Konuyla ilgili kontrollü çalıșma yoktu. Amerikan Üroloji Derneği kılavuzları, prostatın kriyocerrahi ablasyonunu tedavi edici bir yöntem olarak kabul etmektedir; ancak cerrahi ve cerrahi dıșı alternatiflerle klyaslandığında, daha az morbidite ve olasılıkla aynı tedavi etkinliğine sahip minimal invasiv bir yöntem olarak geliștirilmesine rağmen yüksek yoğunluk odaklı ultrasonografi ise hala deneysel olarak kabul edilmektedir.

Girișim yapılmadan düzenli takip edilme kriterlerini yakalayan ancak aktif tedavi șansını kaçırma hissiyle anksiyete yașayan hastalarda, fokal tedaviler iyi alternatifler olabilir. Ancak, fokal tedavi seçeneği düșük ve orta dereceli riski olan hastalar için saklanmalıdır. Radyolojik ve klinik evre sırasıyla T2b ve T2a'nın altında olmalıdır. Ek olarak, adaylar alternatiflerin deneysel olduğu ve zaman içinde tedavi seçeneğinin değiștirilmesine ihtiyaçları olabileceği yönünde bilgilendirilmelidirler. Yakın gelecekte fokal tedavi alternatifleri daha gerçekçi tedavi seçeneklerine dönüșebilirler, ancak kanıta dayalı veri sağlamak için iyi desenlenmiș, çok merkezli randomize prospektif çalıșmalara ihtiyaç vardır.

Anahtar kelimeler: kriyoterapi; yüksek yoğunluklu odaklanmıș ultrason; minimal invazif cerrahi ișlemler; prostat neoplazileri; tedaviler 


\section{Introduction}

The incidence of prostatic carcinoma (PCa) has increased all over the world since the clinical use of prostate specific antigen (PSA) as a screening tool. The screening policy has caused an increase in over detection and over treatments of clinically insignificant tumours that do not threaten patients' life. Overdetections of PCa bring a new dilemma about the patients' quality of life ( $\mathrm{QoL})$. In addition, patients with clinically insignificant tumours experience serious anxiety following the diagnosis of localized prostate cancer and search for curative treatment methods with permanent curative results. For patients meeting the variable criteria for regular follow up visits without intervention but experiencing anxiety with the feeling of losing active treatment options, focal therapies may be ideal alternatives.

Besides radical prostatectomy, cryosurgical ablation of the prostate (CSAP), brachytherapy and high-intensity focused ultrasound (HIFU) have been accepted as alternative treatment options in clinically localized prostatic carcinoma $(\mathrm{PCa})^{1-4}$.

American Urologic Association guidelines have accepted cryosurgical ablation of the prostate as a therapeutic option. However the high-intensity focused ultrasound is still considered as an experimental treatment option, although it has been developed as a minimally invasive procedure with reduced morbidity and potentially with the same therapeutic efficacy in comparison with the surgical or non surgical options.

\section{Cryosurgery of the Prostate}

Cell death is induced by dehydration in cryosurgery, which depends on freezing techniques. Dehydration causes protein denaturation, vascular stasis, microthrombus and direct rupture of cellular membranes by ice crystals. As a result of this cascade, microcirculation is detoriated with apoptosis and ischaemia ${ }^{1-4}$.

For freezing prostate tissue $12-15 \mathrm{~F}$ and $17 \mathrm{~F}$ cryoneedles are used under the guidance of transrectal ultrasound (TRUS). Thermo-sensors and a urethral warmer are placed at the level of external sphincter and bladder neck. A temperature of $-40^{\circ} \mathrm{C}$ is achieved in the mid-prostate gland and the neurovascular bundle with a two freeze thaw cycles.

CSAP is indicated with a tumor extended beyond the prostate $^{1-3}$. The optimal size of the prostate should be below $40 \mathrm{ml}$. In case where the prostate size is more than $40 \mathrm{ml}$, the size should be reduced using hormonal therapies for avoiding the technical difficulties during placing the cryoprobes. PSA levels and Gleason score should be less than $20 \mathrm{ng} / \mathrm{ml}$ and 7 , respectively. Patients having a life expectancy of more than 10 years should be informed about the lack of evidence dealing with long term results of the treatment modalities.

It is important to bear in mind that patients undergoing radical prostatectomy ( $\mathrm{RP}$ ) have a very low mortality risk (2.4\%) for the next 10 years following the surgery ${ }^{5}$. Enhanced techniques like third generation cryosurgery, transperineal, gas driven probes have evolved the outcomes of the modality ${ }^{6-11}$. Globally accepted PSA level after this procedure has not been defined yet, due to lack of certain success and failure universal criteria depending on PSA levels. Some centers accept PSA values $<0.1 \mathrm{ng} / \mathrm{ml}$ as a therapeutic success level, whereas some use the failure criteria of American Society of Therapeutic Radiology and Oncology (ASTRO) which requires three consecutive inclines in PSA level.

If a PSA nadir value is achieved $<0.5 \mathrm{ng} / \mathrm{mL}$ with second generation CSAP, the low risk and high risk patients' biochemical disease free survival rates (BDFS) at five years are $60 \%$ and $36 \%$, respectively ${ }^{6,7}$. A copious of authors had investigated the role of cryoablation. Onik et al. reported 48 patients, who underwent targeted focal therapy with the avoidance of treatment of one neurovascular bundle ${ }^{12}$. The follow up period for all patients was at least two years and overall median follow up was 4.5 years. Disease specific survival was $100 \%$, and $94 \%$ of the cases had a stable PSA. Potency was preserved in 36 of 40 patients (90\%), who were also potent before the treatment. All of them were continent, and 24 of the patients with a stable PSA value and a routine second prostate biopsy one year later had been disease free.

Lambert et al. preferred cryoablation to treat 25 patients with hemiablation of the prostate ${ }^{13}$. They reported that 21 patients $(88 \%)$ were free of biochemical recurrence, which was defined as a reduction of PSA more than $50 \%$ at the 28 th month of follow up. Of seven patients, who underwent post treatment biopsy, two patients had cancer in the contralateral gland and one patient had cancer in the area of the previous cryosurgery. The potency rate was $71 \%$ and there was no urinary incontinence. 
Ellis et al. treated 60 patients with focal cryoablation of one lobe of prostate ${ }^{14}$. Eighty percent of the patients was free of biochemical recurrence during a median follow up of 15 months, which was based on ASTRO's failure criteria of three successive rises in PSA.

In a study, results of 31 patients, who underwent cryotherapy hemi-ablation were reported by Bahn et al. ${ }^{15}$. The biochemical recurrence free rate was $92 \%$ according to ASTRO criteria during a median follow up of 70 months. A mean of 2.3 post treatment biopsies were performed to these patients. Of the 25 patients, who had a follow up biopsy, 24 (96\%) did not have any evidence of cancer. Potency was preserved in $89 \%$ and neither incontinence nor other complications were reported.

Long et al. reported CSAP results of 975 patients, who were enrolled into three risk groups ${ }^{6}$. The study period was 24 months and PSA thresholds were considered $1.0 \mathrm{ng} / \mathrm{mL}$ and $<0.5 \mathrm{ng} / \mathrm{mL}$. The five year BDFS rate for low risk group according to PSA values mentioned above was $76 \%$ and $60 \%$, respectively. Intermediate risk group had a BDFS rate of $71 \%$ and $45 \%$. The value was $61 \%$ and $36 \%$ for high risk group.

A recent meta-analysis studied the results of 566 cryosurgery related publications ${ }^{16}$; although there were no controlled trials, validated biochemical surrogate end points and survival data available for analysis. Depending on the definition of failure and risk groups, progression-free survival (PFS) of cryosurgery was reported to be between 36-92\% (projected 1- to 7-year data). Approximately $72-87 \%$ of cases had negative biopsy results; however none of the data included biopsy results after the use of third generation cryotherapy machines.

PSA was evaluated in $63 \%$ of patients $(110 / 176)$ during a 12 months period with regards to third generation machines ${ }^{6-11}$. Seventy-three percent $(n=80)$ of these patients had a PSA nadir value below $0.4 \mathrm{ng} / \mathrm{mL}$. If a cut off value of $0.4 \mathrm{ng} / \mathrm{mL}$ was used, $64.6 \%(42 / 65)$ of low risk patients would live free of biochemical progression.

Bahn et al. have reported a study having a longer follow up period". The outcomes of 590 patients, who underwent CSAP for locally advanced and localized PCa were analysed. If a PSA cut off value lower than $0.5 \mathrm{ng} / \mathrm{mL}$ was used, seven year BDFS of low, medium and high risk groups would be $61 \%, 68 \%$ and $61 \%$, respectively.
In a recent report, nerve sparing cryosurgery was defined as an experimental option ${ }^{17}$. Nine patients having unilateral $\mathrm{PCa}$, which was confirmed on repeated biopsy specimen, underwent nerve sparing cryosurgery. CSAP was performed to the side of the positive biopsy, whereas negative side was protected against freezing.

\section{Complications of CSAP for Primary Treatment of PCa}

Erectile dysfunction is observed in $80 \%$ of patients and new generation systems seem not to affect the outcome of erectile dysfunction. The complication rates of third generation system are pelvic pain in $1.4 \%$, incontinence in $4.4 \%$, tissue sloughing in 3\% and urinary retention in about $2 \%$ of the cases ${ }^{6-11}$. Fistula formation is a rare occasion and reported in $<0.2 \%$ in modern series. Transurethral resection of the prostate (TUR-P) is required for approximately $5 \%$ of the patients due to subvesical obstruction.

In a clinical phase II trial, 75 men who underwent CSAP have been investigated for quality of life and sexuality following the procedure ${ }^{18}$. Most of the complaints disappeared during a 12 months period after CSAP according to the prostate-specific FACT-P questionnaire. Interestingly, when the data at 36 months was compared with 12 months' data, no significant changes were noted. In terms of sexuality, $37 \%$ of men were able to achieve intercourse 3 years after CSAP.

In a recent, prospective, randomized clinical trial, 244 men having organ confined PCa were enrolled to undergo either CSAP or external beam radiotherapy $(\text { EBRT })^{19}$. Sexual functions of these patients were compared at the postoperative period. EBRT group reported better sexual function after a follow up of three years.

\section{HIFU of the Prostate}

HIFU of the prostate was first reported in 1994 for treatment of benign prostatic hyperplasia. Gelet et al. first reported the results of its use for treating focal prostate cancer in $1996^{20}$. This technique depends on the damage caused by ultrasound's mechanical vibrations over a threshold of human's hearing threshold. It allows the focusing of ultrasound beams on a very narrow area ranging between $1-3 \mathrm{~mm}$ to $8-15 \mathrm{~mm}$, depending on the transducer's characteristics ${ }^{21}$. Tissue damage is achieved by mechanical/thermal effects and 
cavitation $^{22}$. HIFU creates a temperature over $65^{\circ} \mathrm{C}$ and malignant tissues are damaged by coagulative necrosis. This heat produces cavitations due to the release of gas bubbles. Granulation tissue is formed by coagulation necrosis of the prostate with inflammatory response $^{23}$.

There are two commercially available transrectal HIFU devices for treating the prostate: Ablatherm (Edap-Technomed, Lyon, France) and Sonoblate 500 (Focus surgery, Indianapolis, USA). Both systems are approved for clinical use in many countries. The target treatment zone is heated for three seconds and then cooled for six seconds. The upper limit of the size of the prostate that can be treated by HIFU is $50 \mathrm{~cm}^{3}$, due to limitations of ultrasound beams range. Thus, prior to treatment many centers prefer to perform TUR-P or androgen deprivation therapy to reduce the size of the prostate to the proper limits ${ }^{24}$.

HIFU can be performed in the lateral position under general or spinal anesthesia. Ten gr/hour prostate tissue is heated, thus the procedure is time-consuming.

\section{Results of HIFU in Prostate Cancer}

Success criteria and oncological outcome of HIFU in prostate cancer create a dilemma, because there is not an international consensus about the outcome. A limeted number of PCa cases, $<1000$, have been reported in the literature.

In a published review, 150 articles dealing with oncological and functional results of HIFU were reported ${ }^{16}$. Like in CSAP, neither controlled trials and validated biochemical surrogate endpoints nor survival data were available for analysis. According to this recent review, HIFU had a PFS of $63-87 \%$ (3 to 5 year data), however, the median follow up period of these studies was between 12 and 24 months only ${ }^{16}$.

Focal HIFU ablation was initially performed in $10 \mathrm{pa}-$ tients with a first generation machine undergoing subsequent radical prostatectomy ${ }^{25}$. Residual tumour was detected in seven of these patients. In another study, Muto et al. performed HIFU in 70 patients, 29 of them with localized prostate cancer, who had unilateral biopsy based evidence of cancer $^{26}$. The ipsilateral transitional zone and bilateral peripheral zones were focally ablated. Negative biopsy rates at six and 12 months were $88.1 \%$ and $81.6 \%$, respectively, during a median follow up of 34 months without differences between patients undergoing focal and whole gland ablation.
Although sexual function was not assessed, the quality of life evaluation showed no significant differences in urinary morbidity between focal and whole gland therapy based on the UCLA-PCI and IPSS scores.

In one of the largest single center study, the results of 227 patients who underwent HIFU (Ablatherm) for clinically organ confined T1-T2 PCa were analysed after a median follow up period of 27 months (12-121 months). The mean number of cycles per session was $419^{27}$. The projected five-year BDFS was $66 \%$ and it decreased to $57 \%$ in patients with PSA values between 4-10 ng/mL. Forty-three percent of patients required retreatment due to the persistence of the residual desiase. The rate of incontinence and bladder neck stricture decreased over time to $9 \%$ and $6 \%$ from $28 \%$ and $31 \%$, respectively.

In another study, pre-treatment PSA value decreased to $2.4 \mathrm{ng} / \mathrm{mL}$ from $12 \mathrm{ng} / \mathrm{mL}^{20}$. However, positiviness of the prostate biopsies were $50 \%(\mathrm{n}=7)$ during follow-up. Uchida et al. reported a three year biochemical recurrence free survival rate of $82 \%$ for 63 patients with clinical T1 or T2 cancers with the Sonoblate ${ }^{\circledR 28}$. Urethral strictures were noted in $24 \%$ of the patients.

A European multicenter study reported the efficacy of HIFU involving the data of 559 low and intermediate risk PCa patients ${ }^{29}$. During a follow-up of at least of six months, a negative biopsy rate of $87.2 \%$ was reported in 288 men. Re-treatment rate was $28 \%$. After a follow up period of six months, PSA nadir was $1.8 \mathrm{ng} / \mathrm{mL}$ and determined in 212 patients. In addition, it was mentioned that a PSA nadir value might be achieved after 12-18 months following the initial procedure.

Blana et al. reported the outcomes of 146 patients after a median follow-up of 22.5 months, who underwent $\mathrm{HIFU}^{30}$. At the initiation of therapy, mean PSA level was $7.6 \mathrm{ng} / \mathrm{mL}$ and it decreased to $0.07 \mathrm{ng} / \mathrm{mL}$ after three months. However, the median PSA value increased to $0.15 \mathrm{ng} / \mathrm{mL}$ at the end of 22 months. Analysis was available in 137 men and $93.4 \%$ of these patients revealed a negative control biopsy. Treatment failure was found to be strongly associated with PSA nadir $(p<0.001)^{31}$. Treatment failure rates of patients with a PSA nadir of $0-0.2 \mathrm{ng} / \mathrm{mL}, 0.21-1.00 \mathrm{ng} / \mathrm{mL}$ and $>1 \mathrm{ng} / \mathrm{mL}$ were $11 \%, 46 \%$ and $48 \%$, respectively. Same authors have recently updated the outcomes in a study involving the data of 163 men, who were treated for clinically organ confined PCa. The actual DFS rate was $66 \%$ at 5 th year and salvage treatment 
was required in $12 \%$ of patients during a mean $4.8 \pm 1.2$ years of follow-up ${ }^{32}$.

In another study, HIFU was used for treating 517 men having locally advanced or organ confined $\mathrm{PCa}^{33}$. They accepted the biochemical failure criteria included in Phoenix guidelines, as PSA nadir of $+2 \mathrm{ng} / \mathrm{mL}$. The BDFS was $72 \%$ for the entire cohort after a median follow-up of 24 months. The BDFS rate of patients having T1c, T2a, T2b, T2c and T3 stage at five years was 74\%, $79 \%, 72 \%, 24 \%$ and $33 \%$, respectively $(p<0.001)$. The same rate of low/intermediate and high-risk groups at 5 years was $84 \%, 64 \%$ and $45 \%$, respectively $(\mathrm{p}<0.001)$. The BDFS rate of patients, who were treated with or without neoadjuvant hormonal therapy at seven years was $73 \%$ and $53 \%$, respectively $(p<0.001)$. Various degrees of erectile dysfunction was observed at the postoperative period in $28.9 \%(33 / 114)$ of patients who were potent preoperatively.

The records of one hundred and thirty seven patients having PCa undergoing HIFU were evaluated retrospectively in a study ${ }^{34}$. During a mean follow up period of 36 months, disease relapsed in $22 \%$ of the patients. The overall five-year DFS rate was $78 \%$. DFS rate of low, intermediate and high risk group at five years was $91 \%, 81 \%$ and $62 \%$, respectively. Dysuria $(n=33)$ and urge incontinence $(n=16)$ were common side effects and repeated in $24.1 \%$ and $11.8 \%$ of patients after removing the urethral catheter.

Bouiter et al. evaluated the risk of incomplete transrectal HIFU ablation in terms of the location of PCa (basis/mid/apex) ${ }^{35}$. They analysed the outcomes of 99 patients undergoing HIFU ablation (Ablatherm) with a $6 \mathrm{~mm}$ safety margin at the apex. They performed systematic biopsies at three and six months after the initial treatment. Residual cancer was observed in $36.4 \%(n=36)$ of patients. Fifty of the biopsy sextants $(8.4 \%)$ were positive; eight $(16 \%)$ were in the basis, $12(24 \%)$ were in the mid and $30(60 \%)$ were in the apex. Statistical analysis revealed that the mean $(95 \%$ CI) probability for a sextant to remain positive after HIFU ablation was $8.8 \%$ for basis, $12.7 \%$ for mid, and $41.7 \%$ for the apex. Erectile dysfunction and incontinence were less common, when a $6 \mathrm{~mm}$ safety margin was used at the apex. It was mentioned that, in terms of location of residual cancer, apex was significantly the more frequently affected part.

During a mean follow-up period of 47 (2-70) months, Komura et al. reported the oncological outcomes of
144 patients having T1/T2 $\mathrm{PCa}^{36}$. Disease parameters relapsed in $39 \%$ of the patients. Urethral stricture was observed in $40 \%$ of the patients at the postoperative period. Interestingly, the value of five year DFS was significantly better in patients having stricture, when compared with patients without strictures $(78.2 \%$ vs $47.8 \%, \mathrm{p}<0.001)$ and more aggressive treatment was required for the carcinomas located at the apex of the prostate.

\section{Complications of HIFU}

Urinary retention is one of the most common side effects of HIFU and observed in nearly all patients. The patients are catheterized trans-urethrally or via a suprapubic tube for 12 and 35 days $^{20,22,27}$. Bladder neck or urethral strictures seem to be the frequent late side effects according to the reports from whole gland HIFUs. Impotence is not investigated well in most of the studies, however ranges between $20 \%$ and $50 \%$. Urethrorectal fistula is a rare; but challenging complication. The rate of fistulas has been reported exceedingly low in many series due to the use of new devices and modified software in the market, rectal cooling and robotic control of rectal distance.

Elterman et al. evaluated the frequency and type of complications in 95 patients having clinically organ-confined PCa, who underwent HIFU with Sonablate $-500^{\circ}$ device ${ }^{37}$. Two percent of the patients developed significant erectile dysfunction and $17 \%$ (7/41) had significant incontinence during a minimum follow-up of six months. Twenty (21.1\%) and 17 (17.9\%) patients required surgical treatment for late and early inferovesical obstruction, respectively.

\section{Miscellaneous Modalities}

Vascular targeted photodynamic therapy (VTP) involves the generation of cytotoxic agents in situ that results in tissue ablation and cell death. A photosensitizing drug, which is achieved by systemic or local administration, is activated with a specific wavelength light. It causes localized coagulation necrosis and vascular thrombosis around the tip of the optic fiber. The fiber is applied transperineally and ablation volume is titrated to $18 \mathrm{~cm}^{3}$ in size step by step ${ }^{38}$.

The use of the photosensitizer Tookad" (WST09) in the VTP of prostate cancer has been investigated in a recent study. Huang et al. reported that clinically significant volume of normal canine prostate tissue might 
be destroyed with Tookad-VTP ${ }^{39}$. A pilot trial involving six patients, who had undergone focal VTP for clinically organ confined cancer showed evident ablative changes on MRI and achieved an average rate of $67 \%$ PSA declines ${ }^{40}$. Ahmed et al. reported a dose response by an increase in the volume of hypoperfusion observed on the post treatment MRI in $27 \mathrm{men}^{41}$. This technology appears as a promising alternative; however long term follow up and quality of life outcomes need to be defined.

Laser induced interstitial thermotherapy (LITT) is another encouraging alternative that depends on the use of one or two source fibers for targeted necrosis and thermal coagulation. Lindner et al. reported LITT in 12 patients with low risk prostate cancer (T1c or T2a, PSA $<10 \mathrm{ng} / \mathrm{ml}, 30 \%$ or less cores involved). Location was established with 12 sextant biopsies and multiparametric MRI ${ }^{42}$. The most common side effect was perineal discomfort (25\%). The results of the treatment were evaluated by using MRI and biopsies. Four patients had residual tumour in the treated areas while six patients were disease free.

\section{Pretherapeutic Assessment of Candidates for Focal Treatment}

TRUS-guided biopsy regimens are not sufficient for selecting candidates due to systematic and random errors. A template-guided approach with transperineal prostate biopsy is the current gold standart for selecting the patients eligible for focal therapy ${ }^{43,44}$. This approach can rule in and rule out 0.5 and $0.2 \mathrm{~mL}$ volume PCa foci with $90 \%$ certainty, when a $5 \mathrm{~mm}$ sampling frame is used ${ }^{45}$.

The destiny of prostate cancer patients has been dramatically changed since the introduction of prostate specific antigen (PSA) into clinical use in late 1980s. Currently more men are diagnosed with localized, small, less aggressive and non-lethal prostatic carcinoma. Besides radical prostatectomy, cryosurgical ablation of the prostate, brachytherapy and high-intensity focused ultrasound have been accepted as alternative treatment options in clinically localized prostatic carcinoma. For patients meeting the variable criteria for regular follow up visits without intervention but experiencing anxiety with the feeling of losing active treatment options, focal therapies may be ideal alternatives. However, focal therapy options should be spared for patients with low to moderate risks. The radiologic and clinical stages should be below cT2b and cT2a, respectively. In addition, all candidates should be informed that the alternative therapies are considered as experimental and they may need an alternative treatment option in time. Focal therapy alternatives may be more realistic treatment options in the near future; however, well designed multicenter prospective randomized trials are required to provide evidence based data.

\section{References}

1. Fahmy WE, Bissada NK. Cyrosurgery for prostate cancer. Arch Androl 2003;49:397-407.

2. Rees J, Patel B, Macdonagh R, et al. Cryosurgery for prostate cancer. BJU Int 2004;93:710-4.

3. Han KR, Belldegrun AS. Third-generation cryosurgery for primary and recurrent prostate cancer. BJU Int 2004;93:14-8.

4. Beerlage HP, Thüroff S, Madersbacher S, et al. Current status of minimally invasive treatment options for localized prostate carcinoma. Eur Urol 2000;3:2-13.

5. Hull GW, Rabbani F, Abbas F, et al. Cancer control with radical prostatectomy alone in 1,000 consecutive patients. J Urol 2002; 167:528-34.

6. Long JP, Bahn D, Lee F, et al. Five-year retrospective, multiinstitutional pooled analysis of cancerrelatedoutcomes after cryosurgical ablation of the prostate. Urology 2001;57:18-23.

7. Donelly BJ, Saliken JC, Ernst DS, et al. Prospective trial of cryosurgical ablation of the prostate: five-year results. Urology 2002;60:645-9.

8. Han KR, Cohen JK, Miller RJ, et al. Treatment of organ confined prostate cancer with third generationcryosurgery: preliminary multicentre experience. J Urol 2003;170:1126-30.

9. Bahn DK, Lee F, Baldalament R, et al. Targeted cryoablation of the prostate: 7-year outcomes in the primary treatment of prostate cancer. Urology 2002;60:3-11.

10. Koppie TM, Shinohara K, Grossfeld GD, et al. The efficacy of cryosurgical ablation of prostate cancer: the University of California, San Francisco experience. J Urol 1999;162:427-32.

11. De La Taille A, Benson MC, Bagiella E, et al. Cryoablation for clinically localized prostate cancer usingan argon-based system: complication rates and biochemical recurrence. BJU Int 2000;85:281-6.

12. Onik G, Vaughan D, Lotenfoe R, et al. The "male lumpectomy": Focal therapy for prostate cancer using cryoablation results in 48 patients with at least 2 year follow up. Urol Oncol 2008;26:500-5.

13. Lambert EH, Bolte K, Masson P, et al. Focal cryosurgery: encouraging health outcomes for unifocal prostate cancer. Urology 2007;69:500-5.

14. Ellis DS, Manny TB Jr, Rewcastle JC. Focal cryosurgery followed by penile rehabilitation as primary treatment for localised prostate cancer: initial results. Urology 2007;70:9-15. 
15. Bahn DK, Silverman P, Lee F Sr, et al. Focal prostate cryoablation: initial results Show cancer control and potency preseravation. J Endourol 2006;20:688-92.

16. Aus G. Current status of HIFU and cryotherapy in prostate cancer-a review. Eur Urol 2006;50:927-34.

17. Onik G, Narayan P, Vaughan D, et al. Focal 'nerve-sparing' cryosurgery for treatment of primary prostate cancer: a new approach to preserving potency. Urology 2002;60:109-14.

18. Robinson JW, Donnelly BJ, Saliken JC, et al. Quality of life and sexuality of men with prostate cancer 3 years after cryosurgery. Urology 2002;60:12-8.

19. Robinson JW, Donnelly BJ, Siever JE, et al. A randomized trial of external beam radiotherapyversus cryoablation in patients with localized prostate cancer: quality of life outcomes. Cancer 2009;115:4695-704.

20. Gelet A, Chapelon JY, Bouvier R, et al. Local control of prostate cancer by transrectal high intensity focused ultrasound therapy: preliminary results. J Urol 1999;161:156-62.

21. Ahmed HU, Moore C, Emberton M. Minimally invasive technologies in uro-oncology: the role of cryotherapy, HIFU and photodynamic therapy in whole gland and focal therapy of localised prostate cancer. Surg Oncol 2009;18:219-32.

22. Madersbacher S, Marberger M. High-energy shockwaves and extracorporeal high-intensity focused ultrasound. J Endourol 2003;17:667-72.

23. Kennedy JE. High intensity focused ultrasound in the treatment of solid tumours. Nat Rev Cancer 2005;5:321-7.

24. Vallencien G, Prapotnich D, Cathelineau X, et al. Transrectal focused ultrasound combined with transurethral resection of the prostatefor the treatment of localised prostate cancer: feasibility study. J Urol 2004;171:2265-7.

25. Madersbacher S, Pedavilla M, Vingers L, et al. Effect of high intensity focused ultrasound on human prostate cancer in vivo. Cancer Res 1995;55:3346-51.

26. Muto S, Yoshii T, Saito K, Kamiyama Y, et al. Focal therapy with high intensity focused ultrasound in the treatment of localised prostate cancer. Jpn J Clin Oncol 2008;38:192-9.

27. Poissonnier L, Chapelon JY, Rouviere O, et al. Control of prostate cancer by transrectal HIFU in 227 patients. Eur Urol 2007;51:381-7.

28. Uchida T, Onkusa H, Nagata Y, et al. Treatment of localised prostate cancer using high intensity focused ultrasound. BJU Int 2006;97:56-61.

29. Thüroff S, Chaussy C, Vallancien G, et al. High-intensity focused ultrasound and localized prostate cancer: efficacy results from the European multicentric study. J Endourol 2003;17:673-7.

30. Blana A, Walter B, Rogenhofer S, et al. High-intensity focused ultrasound for the treatment of localized prostate cancer: 5-year experience. Urology 2004;63:297-300.

31. Uchida T, Illing RO, Cathcart PJ, et al. To what extent does the prostate-specific antigen nadir predict subsequent treatment failure after transrectal high-intensity focused ultrasound therapy for presumedlocalized adenocarcinoma of the prostate? BJU Int 2006;98:537-9.
32. Blana A, Rogenhofer S, Ganzer R, et al. Eight years'experience with high-intensity focused ultrasonography for treatment of localized prostate cancer. Urology 2008;72:1329-33.

33. Uchida T, Shoji S, Nakano M, et al. Transrectal high-intensity focused ultrasound for the treatment of localized prostate cancer: eight-year experience. Int J Urol 2009; 16:881-6.

34. Inoue $\mathrm{Y}$, Goto $\mathrm{K}$, Hayashi $\mathrm{T}$, et al. Transrectal high-intensity focused ultrasound for treatment of localized prostate cancer. Int J Urol 2011;18:358-62.

35. Boutier R, Girouin N, Cheikh AB, et al. Location of residual cancer after transrectal high-intensity focused ultrasound ablation for clinically localized prostate cancer. BJU Int 2011;108:1776-81.

36. Komura K, Inamoto T, Black PC, et al. Clinically significant urethral stricture and/or subclinical urethral stricture after high-intensity focused ultrasound correlates with disease-free survival in patients withlocalized prostate cancer. Urol Int 2011;87:276-81.

37. Elterman DS, Barkin J, Radomski SB, et al. Results of high intensity focused ultrasound treatment of prostate cancer: early Canadian experience at a single center. Can J Urol 2011;18:6037-42.

38. Trachtenberg J, Weersink RA, Davidson SR, et al. Vascular targeted photodynamic therapy (padoporfin, wst09) for recurrent prostate cancer after failure of external beam radiotherapy: a study of escalating light doses. BJU Int 2008;102:556-62.

39. Huang Z, Chen Q, Dole KC, et al. The effect of Tookad mediated photodynamic ablation of prostate gland on adjacent tissues-in vivo study in a canine model. Photochem Photobiol 2007;6:1318-24.

40. Abdel-Hady ES, Martin-Hirsch P, Duggan-Keen M, et al. Immunological and viral factors associated with the response of vulval intraepithelial neoplasia to photodynamic therapy. Cancer Res 2001;61:192-6.

41. Ahmed HU, Calleary J, Arya M, et al. Dynamic contrast enhanced, pelvic phased array magnetic resonance imaging of localised prostate cancer for predicting tumor volume: correlation with radical prostatectomy findings. J Urol 2007;177:2395-6.

42. Lindner U, Weersink RA, Hadider MA, et al. Image guided photothermal focal therapy for localised prostate cancer: phase 1 trial. J Urol 2009;182:1371-7.

43. Onik G, Miessau M, Bostwick DG. Three-dimensional prostate mapping biopsy has a potentially significant impact on prostate cancer management. J Clin Oncol 2009;27:4321-6.

44. Onik G, Barzell W. Transperineal 3D mapping biopsy of the prostate: an essential tool in selecting patients for focal prostate cancer therapy. Urol Oncol 2008;26:506-10.

45. Crawford ED, Wilson SS, Torkko KC, et al. Clinical staging of prostate cancer:a computer-simulated study of transperineal prostate biopsy. BJU Int 2005; 96:999-1004. 